\title{
STRATEGIC OPTIONS FOR NEWLY ENTERING COMPANIES INTO THE WINE SECTOR IN THE CZECH REPUBLIC
}

\author{
R. Šperková, R. Skýpalová
}

Received: June 30, 2012

\begin{abstract}
ŠPERKOVÁ, R., SKÝPALOVÁ, R.: Strategic options for newly entering companies into the wine sector in the Czech Republic. Acta univ. agric. et silvic. Mendel. Brun., 2012, LX, No. 7, pp. 387-398

Market environment is currently characterised by a constant dynamic development and changing conditions. The wine sector in the Czech Republic has passed and still passes through a number of changes which affect the decisions of business entities that are considering whether to enter the industry or not. The importance of strategic management is on the rise in this area as well as the significance of a company strategies creation which give the company the instructions how to use their distinctive ability and transform it into a competitive advantage.

With regard to the distribution of market shares of each of the companies in the market, it is considered that the market will enter two different size firms, i.e. company A and B, in which the fundamental assumptions have been chosen so that they simulate two extreme examples of enterprises that might emerge in the market. The two chosen types of businesses are proposed recommendations focused on the most effective entry with the use of a methodological tool - GE Matrix (General Electric). For the micro-enterprise (company B) it was a careful entry with minimising the entry investment, differentiation of production and subsequent gradual increase of the market share. For mediumsized enterprise (company A) it means the need of high investments, primarily to the purchase of technology and marketing.
\end{abstract}

wine sector, attractiveness, competitive position, GE Matrix, strategy

The market environment is currently characterised by the constant dynamic development and the changing conditions. Hence it is very difficult for individual companies to define longterm objectives so that they could be achievable in hardly predictable future conditions. Elaborating strategies, that determine the desired long-term direction of the firm, will consolidate company effort for development and prosperity which are the basis for the competitiveness of the company businesses. Companies being currently in the market are exposed to a strong and growing competition. It is therefore the primary task of the management to ensure lasting vitality and existence on the basis of active and reactive creating of a balance between external and internal environment by means of appropriately chosen strategies which then become a strategic advantage (Kotler,
Armstrong, 2004). Companies in many sectors face competitive pressures and the wine sector is not an exception. Few other scopes of activities are so markedly territorially bound with a specific area and this is true for the whole Europe. Even in the Czech Republic it is not full-area widespread (98\% of the wines produced in the Czech Republic originate from the South Moravia, 2\% is produced by the Czech region). In addition, the natural and climatic conditions of the Czech Republic provide uniqueness, originality and exceptional taste to the domestic wines, thus gaining potential advantage on the world market (Šperková, Hejmalová, 2012). The existence of these factors in the context of the physical capabilities of the companies to react to them is an essential prerequisite for the most cost-effective entry of businesses considering an accession into the industry. 
The aim of the work is a formulation of suggestions and recommendations focused on the most effective entry for companies contemplating the accession into the wine sector.

\section{MATERIALS AND METHODS}

For the formulation of suggestions and recommendations for companies contemplating entering into the wine sector are from the methodological point of view used the GE Matrix. The GE Matrix (General Electric) is a modification of the BCG Matrix that is sometimes also called McKinsey Matrix because it is the result of a longterm project led by McKinsey and Company, a consulting firm working for the headquarters of the American enterprise General Electric (McKinsey, Quarterly, 2008). According to Keřkovský and Vykypěl (1998) the creation of the matrix is as follows:

- Determination of the attractiveness criteria of the sector (e.g. a market size, a market growth rate, indicators of break-even point - in particular ROE in the sector, a profitability of the industry, an intensity of the competition, a margin usual in the sector, a degree of differentiation, a fluctuation of demand in this sector, a relationships between customers and suppliers, a variability of demand, a pace of technological innovation, a sector fluctuation rate, an availability of information on the market,an availability of labour, global opportunities, results of the PEST analysis, entry and exit barriers of the sector and a degree of the sector state regulation) and criteria of the competitive position (e.g. a market share, a growth in market share, a quality of the company, a price, costs, an efficiency,an innovation, finances, managerial skills, a productivity).

- Quantification of weights from interval of individual factors. The total of all the weights in the same dimension has to be 1 .

- Determination of the performance intensity of the specific criteria in the sector with the help of scoring scale from the interval $\langle-5 ; 5\rangle$. The value of the weight and the intensity are multiplied and the results (i.e. the score) are recorded. This procedure is applied to both the individual criteria of the sector attractiveness and the competitive position criteria.

- Calculation of the total score. This is the sum of the individual partial results and the calculation of the maximum possible score which are determined as the number of criteria multiplied by a positive marginal interval value of weight and intensity: maximum possible score $=\mathrm{X} \times 5 \times 5$. The percentage score is calculated as:

Percentage score $=\frac{\text { Total score } \times 100}{\text { Maximum possible score }}$.
The resulting percentage score determines the position of the firm in the GE Matrix.

- Recording of the company position within the matrix by a circle whose radius expresses the size of the market share and determines specific strategies (Hejmalová, Šperková, 2011).

The position of the companies within the GE Matrix also specifies the type of the most appropriate strategy which should be selected by the company. According to Thompson, Strickland (1993), the strategies are following: Protect position, Build selectively, Protect and refocus, Invest to build, Selectivity manage for earnings, Manage for earnings, Build selectively, Limited expansion for harvest, Divest.

The GE Matrix is a kind of the portfolio analysis matrix which characterizes its possible exploitation as a static description of company divisions at a given point in time, and as a device that enables to make the recommendation what the focus should be on. A criticism is associated with a small number of factors on entry and a significant simplification in the area of the recommended strategies (the matrix has nine fields but there are only three groups of strategies). Therefore the matrix is primarily used to control the current or prospective divisions of the organization, particularly with emphasis on the balance of the investment portfolio of the enterprise (Žufan, 2002).

\section{RESULTS}

In relation to the distribution of market shares of each of the companies on the market it will be taken into consideration that two different size companies will enter the market (see below). For the compilation of the resulting GE Matrix it is essential to assess the attractiveness of the market and the competitive position of the company.

\section{Market attractiveness}

The attractiveness of the market is affected by many factors. For the purposes of compiling the GE Matrix it is indispensable to assign the weight and the intensity of the influence whose allocation results from the intensity of the impact of various factors on the attractiveness of the sector (Šperková, Hejmalová, 2011).

For a quantitative assessment of the wine sector attractiveness and weigh stating of individual factors a sector attractiveness matrix by Tichá, Hron (2006) was chosen. It is based on 15 factors which influence the sector and on subsequent assignment of 1-10 score according to the conditions that enable the companies to use disposable sources in the sector (Tab I). The final score of individual factors is defined through wine sector attractivity analysis by Hejmalová, Šperková (2011).

Furthermore, the final score of the attractiveness is stated and the results are recorded in the Tab II. 
I: Wine sector attractivity assessment matrix

\begin{tabular}{lllllllllllll}
\hline \multicolumn{1}{c}{ Faktor } & \multicolumn{1}{c}{ Power } & \multicolumn{1}{c}{ Score } \\
\hline 1. Market size & Production, competitors & 1 & 2 & 3 & 4 & 5 & 6 & 7 & 8 & 9 & 10 \\
\hline 2. Growth potential & Rising demand & 1 & 2 & 3 & 4 & 5 & 6 & 7 & 8 & 9 & 10 \\
\hline 3. Profitability & Increase, decrease & 1 & 2 & 3 & 4 & 5 & 6 & 7 & 8 & 9 & 10 \\
\hline 4. Exposure & Competition intensity & 1 & 2 & 3 & 4 & 5 & 6 & 7 & 8 & 9 & 10 \\
\hline 5. Concentration & Dominant companies & 1 & 2 & 3 & 4 & 5 & 6 & 7 & 8 & 9 & 10 \\
\hline 6. Life cycle phase & Increase or decrease & 1 & 2 & 3 & 4 & 5 & 6 & 7 & 8 & 9 & 10 \\
\hline 7. Specialisation & Focus, differentiation & 1 & 2 & 3 & 4 & 5 & 6 & 7 & 8 & 9 & 10 \\
\hline 8. Brand & Value, substitutes & 1 & 2 & 3 & 4 & 5 & 6 & 7 & 8 & 9 & 10 \\
\hline 9. Distribution & Channels, support & 1 & 2 & 3 & 4 & 5 & 6 & 7 & 8 & 9 & 10 \\
\hline 10. Pricing policy & Elasticity, prices & 1 & 2 & 3 & 4 & 5 & 6 & 7 & 8 & 9 & 10 \\
\hline 11. Cost position & High, low & 1 & 2 & 3 & 4 & 5 & 6 & 7 & 8 & 9 & 10 \\
\hline 12. Technology & Uniqueness, innovation & 1 & 2 & 3 & 4 & 5 & 6 & 7 & 8 & 9 & 10 \\
\hline 13. Integration & Vertical, horizontal & 1 & 2 & 3 & 4 & 5 & 6 & 7 & 8 & 9 & 10 \\
\hline 14. Income or outcome & Barriers & 1 & 2 & 3 & 4 & 5 & 6 & 7 & 8 & 9 & 10 \\
\hline 15. Influence of dynamic & Positive, negative & 1 & 2 & 3 & 4 & 5 & 6 & 7 & 8 & 9 & 10 \\
\hline
\end{tabular}

Source: Own work

II: Quantification of the factors of the market attractiveness for the wine sector

\begin{tabular}{|c|c|c|c|}
\hline Factor & Weight & Influence intensity & Score \\
\hline Market size & 0.13 & 4 & 0.52 \\
\hline Growth potential & 0.14 & 5 & 0.70 \\
\hline Profitability & 0.10 & 2 & 0.20 \\
\hline Exposure & 0.04 & 3 & 0.12 \\
\hline Concentration & 0.05 & 2 & 0.10 \\
\hline Life cycle stage & 0.02 & 5 & 0.10 \\
\hline Specialization & 0.03 & 1 & 0.03 \\
\hline Brand & 0.07 & 2 & 0.14 \\
\hline Distribution & 0.06 & 2 & 0.12 \\
\hline Pricing policy & 0.04 & 3 & 0.12 \\
\hline Costs position & 0.03 & 2 & 0.06 \\
\hline Technology & 0.06 & 4 & 0.24 \\
\hline Integration & 0.05 & 1 & 0.05 \\
\hline Possibility of entry/exit & 0.09 & 1 & 0.09 \\
\hline Influence of dynamic changeable forces & 0.09 & 4 & 0.36 \\
\hline Total & 1.0 & & 2.9 \\
\hline
\end{tabular}

Source: Own work

\section{Competitive position}

In the assessment of the competitive position it is necessary to take into account the individual factors resulting from the Porter's model of five dynamic forces (Porter, 1994) which include a rivalry among existing competitors, a threat of substitutes, a threat of entry of new firms into the sector, a bargaining power of suppliers and customers, and other factors that include a quality of the production, costs of the production, a level of the promotion, an intensity of advertising, a company image, a property and investments, a technical and technological level, a financial situation, distribution benefits, a benefit of the company seat, etc. All of these factors are specific to individual businesses where the calculations of the weight, the factor impact intensity and the score have to be carried out on the basis of a situation in which the enterprises are located (Tomšík, Sedlo, Šperková, 2007). Thus it is not possible to state the total score of the competitive position for the whole sector.

Competitive position of individual companies is determined through creating a competitive groups' map in the wine sector and evaluating of their competitive position resulting from the Porter's model of the impetus of competition in the industry. 
The final score of individual factors is specified from executed analyses by Šperková, Hejmalová, (2011) and Šperková, Hejmalová, (2012).

In this context of the assessment of the competitive position and the subsequent strategy suggestions for newly entering businesses, two sizes of companies will be considered which model-fit into competitively distinct groups on the market.

\section{Company A}

Firstly, it is considered a medium-sized company with expected annual turnover of over 100 million CZK, with more than 70 employees and an annual production of around five million bottles. The legal form of the business is a limited liability company. It is assumed that the company will have sufficiently strong capital background and enough free financial resources. It will have an access to technology and an ability to produce high-quality production in a large volume. The company headquarters seat will be in one of the wine-growing regions. Quantification of its competitive position is listed in Tab. III.

In terms of weight, the financial situation is very important for the company because it has to deal with high initial costs, and also the level of promotion and advertising which must not be ignored as the firm will most likely face a retaliatory response by the existing competitors. The company also must not forget about the quality of production and the related technological equipment. The lowest weight has the advantage of company headquarters seat because of the assumption that the venture will be based in one of the wine-growing regions, which cannot bring any benefit from this significant competitive advantage as other firms in the market will situate their headquarters in a similar place.

\section{Company B}

Secondly, it is considered that the market is entered by a micro-enterprise with expected annual turnover up to 0.2 million CZK, having 2-5 employees and its annual production being of around 7 thousand bottles. A legal form of the business is a limited liability company. The seat of the company is also in the wine-growing region but the enterprise will not have sufficient financial resources; most of the initial capital will be invested in the purchase of technology (mostly second-hand) and in the initial costs for company establishment. However, the firm will be able to produce highquality production in small quantities. In the beginning they will not consider a purchase of its own vineyards. A quantification of their competitive position is listed in the Tab. IV.

From the point of view of the weight, the financial situation is very important for the company, because it has to deal with high initial costs for building a company and its image. However, considering the size of the business, they may not expect a strong retaliatory measures by existing competitors as the other micro-enterprises have limited financial resources and market leaders will not probably regard it as an important competitor. Nevertheless, the enterprise must not forget to try to attract customers using its high quality production. The lowest weight has the advantage of company headquarters because it is presumed here that the enterprise will be based in one of the winegrowing regions and thus it cannot benefit from this significant competitive advantage.

\section{Suggested recommendations}

From the calculated figures of the coefficients of the attractiveness of the wine sector and the

III: Quantification of the competitive position of the company A

\begin{tabular}{lccc}
\hline \multicolumn{1}{c}{ Factor } & Scale & Intensity Influence & Score \\
\hline Threat by newly entering companies & 0.08 & 2 & 0.16 \\
Intensity of the rivalry among existing companies & 0.09 & 5 & 0.45 \\
Substitute pressure & 0.05 & 4 & 0.20 \\
Negotiating impact of suppliers & 0.07 & 2 & 0.14 \\
Negotiating impact of customers & 0.08 & 3 & 0.24 \\
Influence of the government & 0.06 & 5 & 0.30 \\
Quality of the production & 0.06 & 5 & 0.30 \\
cost of production & 0.07 & 4 & 0.28 \\
Level of promotion. advertising intensity & 0.10 & 3 & 0.30 \\
Company's image & 0.08 & 2 & 0.16 \\
Property and investments & 0.07 & 5 & 0.35 \\
Technical and technological level & 0.04 & 4 & 0.16 \\
Financial situation & 0.11 & 5 & 0.55 \\
Distribution advantages & 0.03 & 1 & 0.03 \\
Advantage of company headquarters seat & 0.01 & 2 & 0.02 \\
\hline Total & 1.0 & & 3.6 \\
\hline
\end{tabular}

Source: Own work 
IV: Quantification of the competitive position of the company B

\begin{tabular}{lccc}
\hline \multicolumn{1}{c}{ Factor } & Scale & Intensity Influence & Score \\
\hline Threat by newly entering companies & 0.08 & 4 & 0.32 \\
Intensity of the rivalry among existing companies & 0.09 & 1 & 0.09 \\
Substitute pressure & 0.05 & 2 & 0.10 \\
Negotiating impact of suppliers & 0.07 & 1 & 0.07 \\
Negotiating impact of customers & 0.08 & 2 & 0.16 \\
Influence of the government & 0.06 & 3 & 0.18 \\
Quality of the production & 0.07 & 4 & 0.28 \\
Cost of production & 0.03 & 2 & 0.06 \\
Level of promotion. advertising intensity & 0.06 & 1 & 0.06 \\
Company's image & 0.08 & 2 & 0.16 \\
Property and investments & 0.05 & 1 & 0.05 \\
Technical and technological level & 0.07 & 4 & 0.28 \\
Financial situation & 0.15 & 3 & 0.45 \\
Distribution advantages & 0.03 & 1 & 0.03 \\
Advantage of company headquarters seat & 0.03 & 1 & 0.03 \\
\hline Total & $\mathbf{1 . 0}$ & & $\mathbf{2 . 3}$ \\
\hline
\end{tabular}

Source: Own work

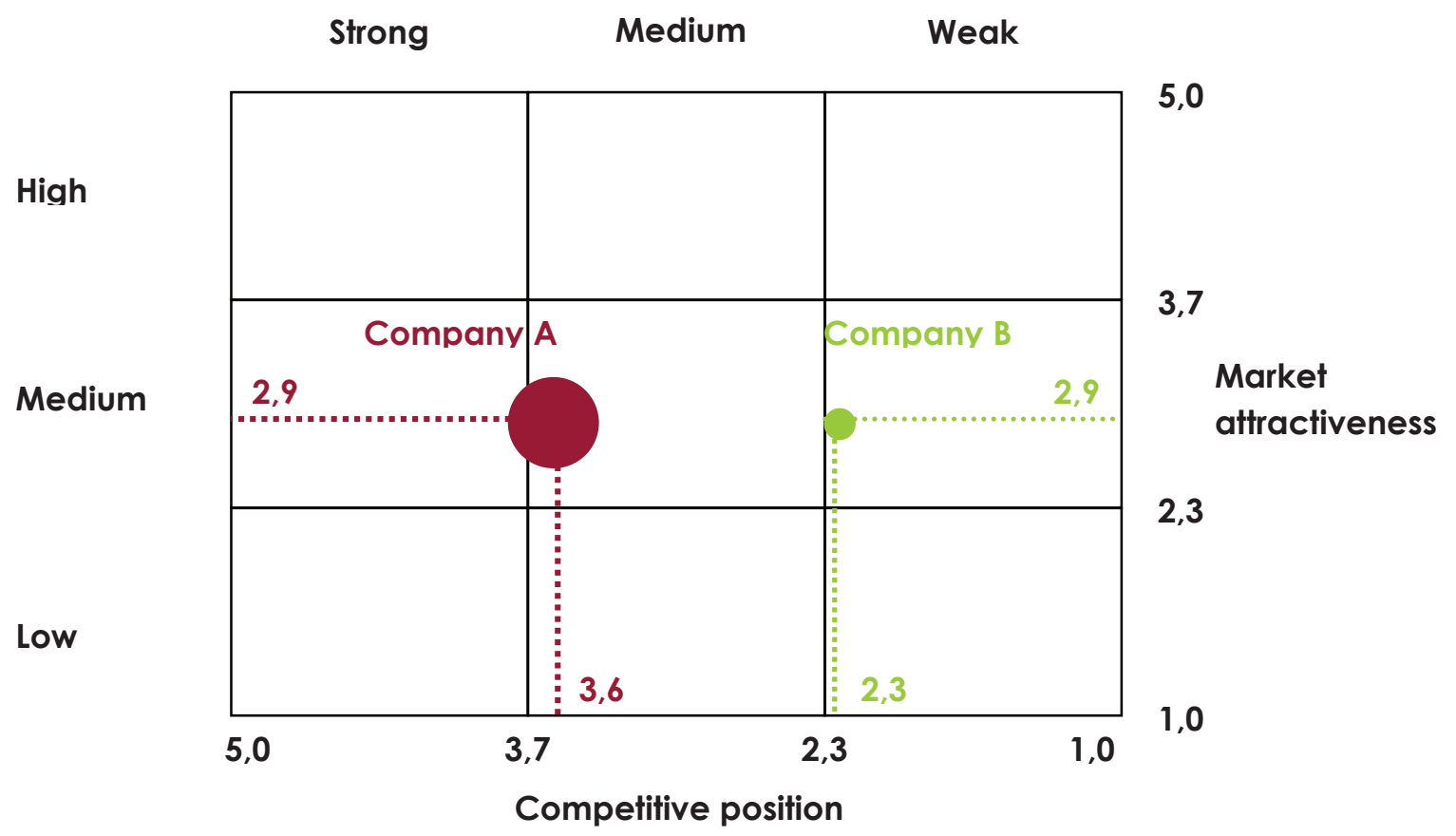

1: GE Matrix for company $A$ a B

Source: Own work

competitive position of the company $A$ and B, the final GE Matrix is compiled (Fig. 1). The recommendations are then stated on the basis of the position in the quadrant that each of the emerging businesses has joined.

\section{Company A}

The competitive position of the company A has been amounted to 2.9 and the attractiveness of the wine sector to 3.6, which specifies the position of the company in the section Selectivity manage for earnings of the GE Matrix (Fig. 1). This square can be interpreted as an average position of the company in the medium attractive sector. However, a closer look at Figure 1 shows that the competitive position of the company is very close to Build selectively.

For newly entering businesses it means a big chance in getting long-term profits even if not too high (the overall profitability of the sector is low) and also future obtaining of a stable customer base due to the existence of production spaces and to a long historical tradition in the consumption of 
wine. On one hand, the company could be helped by the legislative actions in the Czech wine market primarily in the form of zero consumption tax on still wines and by the existence of many kinds of grants or financial subsidies form the state, the EU or non-government organizations. On the other hand, the government's policy is also a very important barrier of entry into the industry where the emerging body does not have to only comply with all the statutory conditions generally applicable to a business in the Czech Republic but it also has to follow the law of wine-growing and viticulture. The firm has to expect a great response on the part of the existing competitors on the market because according to its size and capital base (see above the chosen assumptions) it is more than likely that the company will try to gain significant market share and thus penetrate among ten most important competitors. In addition, the company will face a high initial business costs and in the early years it will not achieve economies of scale. Moreover, the firm has to find suitable suppliers in the wine sector who do not have too much negotiating power. A bigger problem for the company might be finding a suitable customer and problems with distribution. Since the company expects a large amount production, it will be necessary to penetrate into the retail chain stores which have a wide range of customers and also a great negotiating power.

The position of the enterprise within the GE Matrix is in the Selectivity managed for earnings. On this basis, it is appropriate for the company to proceed with caution. The essence is to ensure growth and focus on the care of the company. The firm should invest in monitoring of all processes in the form of a complex company information system. It also has to consider the possible risks associated with investing, to carry out selective choice and to give priority to short-term investment. On the other hand, the position of the company A is close to the Build selectively section, which suggests putting greater emphasis on minimizing and maintaining costs as well as its own position.

On the whole it is possible, due to the new company which intends to enter the wine market in the profile of the company A (see above the chosen assumptions), to recommend the following:

- The complex monitoring of the market before the entry into the sector concentrated on competitor's recognition (especially 10 most important competitors on the market).

- The seat of the company has already been assumed in the wine-growing region but more specifically, it would be appropriate to select it in the vicinity of potential suppliers in order to save subsequently transport costs of raw materials.

- Furthermore, the company should invest in the technical equipment based on new technologies which could result into more efficient production than its competitors and into reducing the costs. The enterprise should also purchase a company information system which will facilitate the administration and monitoring of the business processes. These investments will need to be extended by purchasing appropriate premises for the production and storage of the wine if it is necessary to adhere to the optimum temperature, humidity and light because these factors influence the resulting quality of the wine. Here it is budgetwise to buy and renovate already existing premises.

- From the perspective of employees it is appropriate for the firm to hire trained experts (at least around ten workers in the different specializations in e.g. production, sales, marketing, finance, laboratory) and workers without professional qualifications (e.g. for unskilled work, cleaning, surveillance). With regard to the assessment of the structure of education in the population and the development of unemployment, it is possible to conclude that there are enough experts in the job market in viticulture who are willing to work. According to the progression of their average salaries and the projected company financial situation (see above the chosen assumptions) the enterprise is able to obtain skilled professionals with long term experience by offering 10 to $20 \%$ above the average monthly income. Consequently, they can train workers without professional qualifications who are used for unskilled manual work. Furthermore, the company could broaden its employee base by part-time workers, especially students of professional wine schools through which they would be provided the necessary practice and the firm would get cheap seasonal labourers.

- The enterprise should set aside part of the financial resources for marketing and it should not underestimate the choice of a suitable marketing strategy (in this aspect the firm should proceed very aggressively). It would be appropriate to hire a specialized advertising agency which has enough experience in the field and that will help the company to respond adequately to any retaliatory measures on the part of the existing competitors in the market in this area as well as will create an overall image and will provide a complex approach to the promotion of the company and to attracting customers.

- To be competitive, the enterprise has to enter the market with the same scope of production as its competitors and thus offer the customer the same assortment of wines. Taking into the consideration the proposed scale of production, the business should focus on a wide range of customers and try to penetrate with its production to retail chain stores. Due to the fact that no company in the market has been able to satisfy all customer segments so far, it is appropriate for the company to set aside $20 \%$ of their production capabilities and within this budget to concentrate on the segment of new adventure hunters and offer them different products than the competitors (e.g. specialisation in aromatized wines - the possibility of cooperation with professional wine 
schools). Distribution of such products should primarily be via specialized wine shops. A wine e-shop should be established as an additional service. It is not recommended for the enterprise, at least in the early years of business, to open their own shop, because it means a considerable capital expenditure as well as specialization requirements. Initially the company should concentrate solely on the quality of production and its effectiveness.

- A company should not omit the support from the state, the EU and the non-governmental organizations. It should focus on the identification of all the conditions for their obtaining and should attempt to fulfil them. Thus the enterprise will obtain an additional source of incomes which can effectively invest.

- Furthermore, it is still possible to use the aid from European funds which are dedicated to e.g. a construction of training centres, etc. In case that the company decides to contemplate using these funds, the enterprise should first determine all the conditions which they have to carry out before gaining them and subsequently assess whether it is even able to reach this goal.

- According to the low profitability of the sector and the high capital costs, the firm in the first years of its existence will not achieve a profit; therefore it should consider all other investments. Hence it is not appropriate for the company to invest in their own vineyards but on the contrary they should focus on buying grapes from growers, which is supported by bargain purchase prices and by a possible exploitation of quantitative discounts.

\section{Assessment of implementation costs of selected recommendations for company $A$}

These figures are only indicative. In the implementation of each individual recommendation the actual amount of expended costs will depend on a specific provider.

The calculation of the total costs of business activities of this size company is dependent on the particular financial possibilities of new entrants. The total costs can be about 150-200 million CZK (the figure has been established on the basis of consultations with experts in the sector). These costs include the cost of the company establishment of around $10000 \mathrm{CZK}$, annual labour costs of 70 staff (an average gross wage in agriculture for the year 2010 is included here, i.e. 18.4 thousand CZK, the figure is increased for ten employed experts by 20\%) as well as labour costs of 50 part-time labourers of about 26 million CZK, the costs of production premises (they will be bought and renovated) are approximately 38 million CZK, the costs of technical equipment and technology of about 51 million CZK, the costs of distribution and sale of products of approximately 8 million CZK, the costs of storage and the construction of the cellar of about 6 million
CZK, the costs of advertising of about 26 million CZK and other costs of about 10 million CZK.

With regard to the implementation of the company marketing strategies, the enterprise should realize a complex nationwide marketing campaign. The most appropriate promotional (communication) tools would be advertising on the Internet, advertising through billboards and via the print media. The ideal duration of advertising campaign is two months (NetMonitor, 2012). The advertisements will be placed on one of the most visited websites <idnes.cz〉, 〈seznam.cz〉, 〈novinky. cz $>$ and $<$ google.com $>$ (NetMonitor, 2012). Prices for renting advertising space on those portals depends on its size and location within the page and about 200 thousand CZK per week can be expected (News, 2012). The price for the eight-week advertising on all of the above mentioned portals is 6.4 million CZK (Data.idnes, 2012). It will also be taken into consideration the advertisement placement on billboards located throughout the Czech Republic. The monthly rental averages are around 84 thousand CZK there (NetMonitor, 2012). Thus the price for two- month rental for 100 billboards is 16.8 million CZK. It is inevitable to calculate the costs of printing which is around 400 thousand CZK (depending on the level of the graphic design). The printed form of the ads will be directed to the national edition of the newspapers i.e. Mladá Fronta Dnes, Rovnost and Hospodáŕské noviny. The price here for two months would reach approximately 2.5 million CZK (Marfa, 2012). Last but not least, it is important to include the realization and maintenance of web pages with the e-shop and a profile placement on social networks, which would cost approximately 300 thousand CZK per year (Sunitka, 2012).

\section{Company B}

The competitive position of the company B was amounted to 2.3 and the attractiveness of the wine sector to 3.6, which specifies the position of the company in the sector Limited expansion for harvest of GE Matrix (Fig. 1). This square can be interpreted as a weak competitive position of the company in the medium attractive sector. However, a closer look at Figure 1 shows that the competitive position of the company is almost approaching the Selectivity manages for earnings section.

For newly entering business which decides to establish a company in the size of the company B (see above the chosen assumptions), it will mean considerable initial problems. Due to high initial costs associated with the establishment of the company and the lack of permanent customers, the enterprise cannot count on achieving profitability in the early years of business. Furthermore, it is not certain that in future the situation will be more favourable for the enterprise (the overall profitability of the sector is not too high) and that the company will attract regular customers. The firm will also face the difficulty of accessing to distribution channels. Owing to its financial situation and the expected 
low production volume it will be a problem to get the company production to retail chain stores. In addition, due to the fact that the brand will be unknown, the cooperation with wine shops would be problematic. Another inconvenience may occur when selecting suitable suppliers because most of them already have contracts with existing companies in the sector. On the other hand, the enterprise may not expect much retaliatory measures from the existing competitors on the market. This is due to the fact that enterprises of a similar size do not have enough financial resources nor a strong competitive position for an aggressive response. Ten of the biggest players on the market might not consider this newly entrant firm a significant competitor. Therefore, they may not focus on it in the context of retaliatory measures. The company could also be helped by the legislative steps in the wine market of the Czech Republic primarily in the form of zero consumption tax on still wines, the existence of variety of grants and financial subsidies from the state, the EU and the non-governmental organizations, the existence of production spaces and long-standing historical tradition in the wine consumption. Market segmentation is crucial for the enterprise and the fact that no company in the market is able to satisfy all segments of customers.

The position of the firm within the GE Matrix is in the Limited expansion for harvest section which represents a very slow increase. The process does not have be too accelerated because some companies tend to extend their strength and market share at all costs which might be significantly financially exhausting. The position of the company in GE Matrix is very close to the Selectivity managed for earnings section, which stands for ensuring the growth and focusing on the enterprise maintenance. Thus even if it expands, it should take care of itself, make the production more effective and consider very carefully each investment to avoid potential losses and/or bankruptcy.

Generally it is possible to provide to the enterprise which intends to enter the wine market in the profile of company B (see above the chosen assumptions) the following recommendations:

- Before entering the sector the company B should carry out a complex market monitoring with a focus on regional or local market. It should target local competitors in the area of business, find out its customer potential and possible gaps in the market.

- The seat of the company has already been presupposed in the wine-growing region, however, it would be appropriate in a location with enough potential customers and minimum competitors alternatively in a famed area with a tradition of viticulture (e.g. Moravian wine trails).

- From the point of view of the initial investment the position is rather unfavourable due to its poor financial situation (see above the chosen assumptions). The company cannot afford to purchase modern technologies and achieve economies of scale. Therefore it is more advantageous for the firm to buy a second-hand but still functional device and, subsequently, in the case of profit to renew it. As regards the business premises it is appropriate to make use of the owner's housing (if it is at the appropriate place - see above) or to rent an adequate space. The purchase would be in this case very costly.

- From the perspective of employees a company cannot afford a broad spectrum of workers as it was in the previous case. It is appropriate to involve directly the owner and his/her family members alternatively to employ one expert in wine-making who will lead the process of production. The demand of seasonal work can be covered by parttime seasonal labourers primarily chosen from the ranks of the owner's acquaintances, which could slightly reduce the labour costs.

- The advantage for the company is that it does not have to be afraid of strong retaliatory measures on the part of competitors therefore the enterprise does not need to spend large financial resources on aggressive advertising campaigns. It seems to be effective to use an introductory form of advertising at regional level. The image should be based on a production quality, on a specialisation and on a providing complex customer services. It should also pay attention to the formation of marketing strategy which should be patterned on the stroke strategy, implemented mainly through the Viticulture Fund, the Union of winemakers of the Czech Republic, the National viticulture centre, the Moravín, the Agrarian Chamber of the Czech Republic and the Partnership Fund, and join their projects (Bublíková, 2011).

- To be competitive, the company has to enter the market with the same scope of production as its closest competitors and offer the customers the same assortment of wines. However, with regards to the planned scale of production, it is necessary to focus only on the narrow spectrum of customers and specialize more. It is advantageous to get customers from the environs alternatively to attempt to poach customers from the competitors. Thus it appears appropriate for this type of business the distribution through direct sales associated with the establishment of a small shop directly at the premises of the company as well as the establishment of a wine e-shop. An important feature is a significant differentiation from competitors, i.e. in the form of a wide spectrum of accompanying services (e.g. accommodation, a degustation, a sommelier, technical advice, gifts with purchase).

- A crucial role is played by various forms of a financial support provided by the state, the EU or the non-governmental organizations. The enterprise should be interested in it even before entering the market and get acquainted with all the conditions necessary for their obtaining. Consequently, the company should adapt to these 
conditions and apply for the subsidies forthwith. The resources thus obtained can serve as a very important source of financing in the start-up period when the profits may not be achieved.

- From the point of view of investments, it is good to prefer initially a short-term investment and to consider carefully each of the investments both in terms of its feasibility and return ability. After the company having sufficient cash flow and starting earning profits it is appropriate to execute a reverse vertical integration and invest in the purchase of its own vineyard. The company will have the possibility of planting their own varieties (of course after grubbing-up those existing) and of greater specialization.

\section{Assessment of implementation costs of selected recommendations for company $B$}

The quoted figures are only rough. The actual cost amount will depend on the specific provider within the period of realization of individual recommendations.

The firm will need financial resources to start business activities which are necessary to cover the operating costs until these expenses can be reimbursed from the sales. Furthermore, the enterprise has to bear in mind the expenditure related to the purchasing of technologies (these may be second-hand but functional), to the establishment of its own shops and a cellar and other costs. Tab. V shows an example of the amount of such costs.

The company will consider three full-time employees of which at least one is an expert in the field of wine and will lead the process of production

V: The estimated costs associated with the entry of company B to the sector in $\mathrm{CZK}$

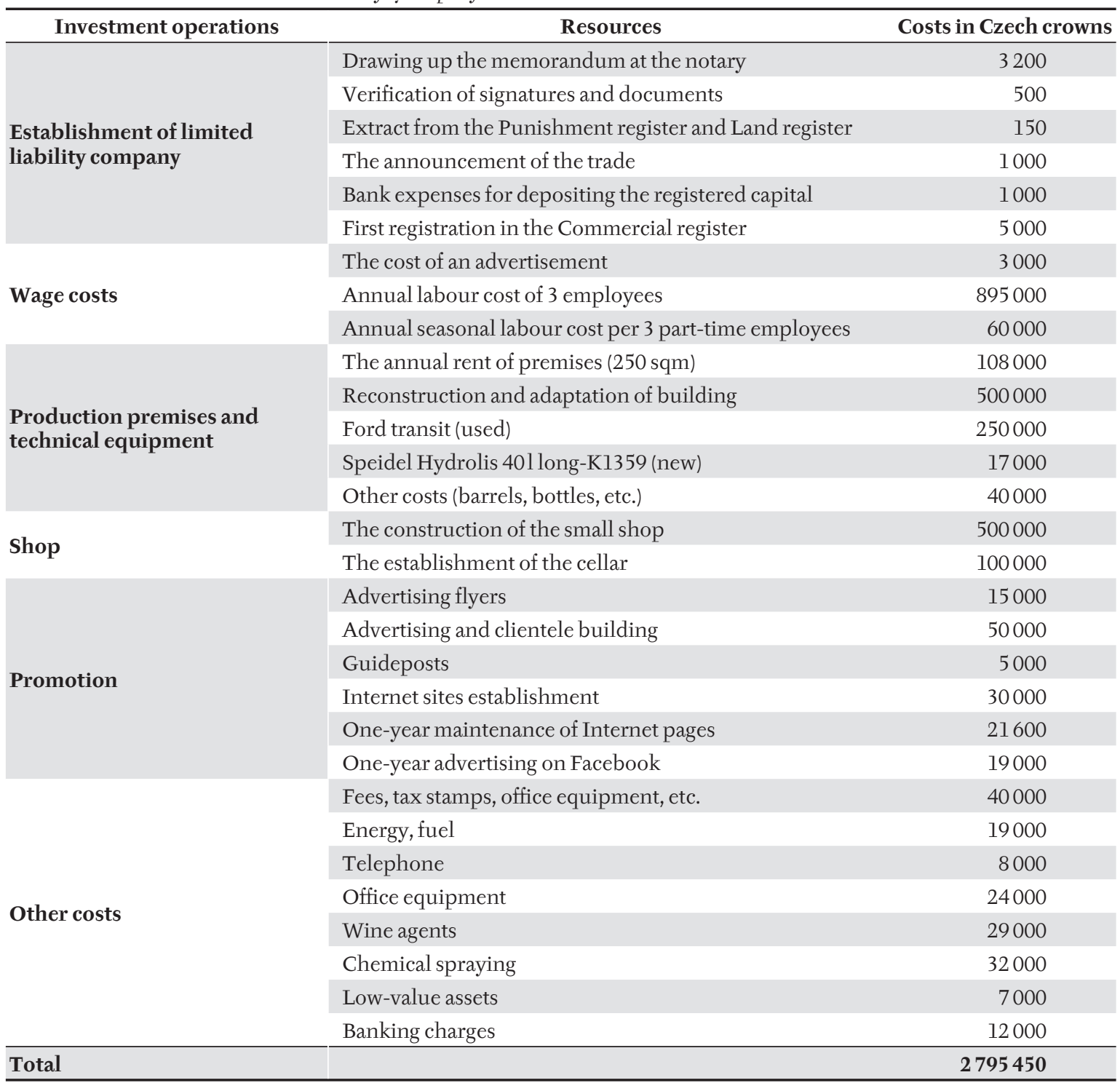

Source: Own work, Print 24 (2012), Studiobambasek (2012), Biopro (2012) 
(provided that the owner or the family members do not have sufficient expertise in the field). To obtain the workers it is inevitable to advertise the vacancies. Advertising through employment offices is not subject to any charges. On the contrary, the state provides financial benefits to the employers who offer jobs to registered candidates (Ministry of labour and social affairs, 2011). If a company decides to advertise via Internet portal <Práce.cz>, which allows a simple input of advertisements by employers from the personal computer as well as a strong public awareness of the portal (NetMonitor, 2012), the price of one-month publishing of the advert is $2960 \mathrm{CZK}$. The monthly gross labour costs of one worker is about 18.4 thousand CZK (this is the average wage in agriculture in 2010 , according to the Czech Statistical Office) and the costs of social and health insurance in this case is 6440 CZK monthly per person, which is 35\% of the gross wage in 2012 ( MLSA, 2011). The company will consider hiring three seasonal workers on the bases of a part-time contract. Here the labour costs could reach about 60 thousand CZK.

In terms of promotion, it is appropriate to focus on the introductory form of advertising in the form of print advertising flyers where with 10000 leaflets the estimated price is around 15 thousand CZK (Print 24, 2012). The graphic design and leaflets distribution might be executed by the owners themselves therefore this does not require any additional financial costs. The company should also organize for free an opening ceremony with own production tasting. The cost of the realization of such an event, including the accompanying programme (i.e. renting a musical group playing for listening and/or dancing) would cost about 50 thousand CZK. Additional financial resources would be needed for installing signposts indicating the location of the business premises. Here, the costs amount to $5000 \mathrm{CZK}$. It would also be appropriate to establish a website with a simple editorial system and SEO optimization containing the e-shop with the wine sales ranging between 20 and 35 thousand CZK (Yashica, 2012). Regarding the administration and management of the websites and the location of the profile on social networks the company has to expect $12600 \mathrm{CZK}$ (i.e. $12 \times 1800$ ) per year (Studiobambasek, 2012). The price of advertising on Facebook is based on a credit system which implies that the company pays in advance a certain amount of money and with each click this amount decreases. The price per click is 7.6 CZK on average (Sunitka, 2012). The total cost of start-up advertising is approx. 140.6 thousand CZK.

\section{DISCUSSIONS}

This proposal for recommendation for the enterprises that consider entering the wine sector engages the GE Matrix. Its construction is based on the market attractiveness evaluation and the competitive position of the company. The matrix has been criticized within the practical usage due to its static view of the situation, some simplification on the entry and in the area of the recommended strategies (although the matrix has 9 fields only three groups of strategies are distinguished). Furthermore, in the context of the assessment of competitive position, factors that are specific for the firm are also considered.

To eliminate the above mentioned drawbacks two different newly entering companies (A and B) were taken into account and the initial assumptions simulate two extreme examples of enterprises that can emerge in the market. Since only entering businesses were involved, the criticized simplification of initial information and resulting strategies has rather seemed to become an advantage. The companies have not taken any action in the sector so far, therefore they have not known several indicators yet. In addition, effective and simple recommendations according to corresponding squares has been recommended, which facilitate their initial entry into the sector the static view of the situation in this case is no longer considered to be problematic). After launching the business it would be appropriate for the enterprises to choose a different strategy-making tool, e.g. the SPACE Matrix.

\section{SUMMARY}

The wine sector in the Czech Republic has passed and still passes through a number of changes which affect the decisions of business entities that are considering whether to enter the industry or not. It is in this area where the importance of strategic management and defining business strategies have been increasing, which instructs the firm how to use their distinctive abilities and transform them into a competitive advantage. From this perspective, it is evident that the core of the business strategy is so-called competitive strategy which enables the most effective entry to the sector and building a strong competitive position on the market.

According to the distribution of market shares of individual companies in the market, it is considered that the market will enter two different size firms, i.e. company A and B in which the fundamental assumptions have been chosen so that they simulate the two extreme examples of enterprises. The two chosen types of businesses are proposed recommendations focused on the most effective entry using a methodological tool - GE Matrix. 
The company A is a medium-sized enterprise with expected annual turnover of over 100 million CZK. It has more than 70 employees, annual production of around 5 million bottles and it is situated in one of the wine-growing regions. It also has a sufficiently strong capital background, enough free financial resources and the know-how of constructing high-quality output at a great volume. This company is recommended, in particular, to monitor the market complexly before the entry into the sector, to invest in the technical equipment, in new technologies, in the information system and production premises. Moreover, the enterprise should hire experienced experts as well as labourers without professional qualifications including seasonal workers, choose the appropriate marketing strategies, alternatively hire advertising agency for a formation of the overall company image. As regards the sales, the firm should focus on a wide range of customers and penetrate the retail chain stores, and also earmark $20 \%$ of their production and utilize it in focusing on a segment of new adventure hunters. The enterprise should always consider carefully the amount of any investment. The costs of entry of the company A to the wine sector could oscillate around 150-200 million CZK.

Company B is a micro-enterprise with expected annual turnover more than 0.2 million CZK. It has 2 to 5 employees, the estimated annual production is about 7 thousand bottles and its seat is situated in one of the wine-growing regions. Furthermore, there is a weak capital background - most of the initial capital is invested in the purchase of technology and the initial costs and in the know-how of constructing high-quality production in a small volume. This company is highly recommended to execute a complex market monitoring before entering the wine sector. Moreover, the investments in second-hand but functional technology and its subsequent renovation is appropriate as well as using of the owner's housing or business premises renting. Company B should employ one expert in viticulture, train family members and hire seasonal labourers. The firm should focus on the introductory form of advertising at regional level and on the quality based image, specialisation and providing complex customer services alternatively make use of the stroke strategy. Its production should be specialized and distributed primarily via direct sales and e-commerce. The total costs of the entry of the company B to the wine sector could oscillate around 3 million CZK.

\section{REFERENCES}

BUBLÍKOVÁ, L. a kol., 201l: Situační a výhledová zpráva. Réva vinná, víno. Praha: MZe ČR, 92 s. ISBN 978-80-7084-982-8.

HEJMALOVÁ, H., ŠPERKOVÁ, R., 201l: Assessment of attractiveness of the wine-production industry in the Czech Republic. Acta Universitatis Agriculturae et Silviculturae Mendelianae Brunensis, sv. LXI, č. 2, s. 89-98. ISSN 1211-8516.

KEŘKOVSKÝ, M., VYKYPĚL, O., 2006: Strategické řízení - Teorie pro praxi, 2. vyd. Praha: C. H. Beck, 206 s. ISBN 80-7179-453-8.

KOTLER, P., ARMSTRONG, G., 2004: Marketing. 1. vyd. Praha: Grada Publishing, 855 s. ISBN 80247-0513-3.

McKINSEY QUARTERLY. Garant, Enduring Ideas, 2011: The GE-McKinsey nine-box matrix. [online]. poslední revize 2008 [cit. 2011-09-21]. Dostupné z: <https://www.mckinseyquarterly. com/Enduring_ideas_The_GE-McKinsey_ninebox_matrix_219>.

ŠPERKOVÁ, R., HEJMALOVÁ, H., 2011: Hybné změnotvorné síly v odvětví vinařství. In Sborník příspěvků z vědecké konference INPROFORUM 2011. 1. vyd. České Budějovice: Jihočeská univerzita v Českých Budějovicích Ekonomická fakulta, s. 419-427. ISBN 978-80-7394-315-8.

ŠPERKOVÁ, R., HEJMALOVÁ, H., 2012: Intensity of rivalry among existing competitors in the winemaking branch. Acta universitatis agriculturae et silviculturae Mendelianae Brunensis, sv. LX, 2012, č. 2, s. 429-436. ISSN 1211-8516.

THOMPSON, A. A., STRICKLAND, A. J., 1993: Strategic Management. Concept and Cases. 7. vyd. New York: Irvin, 948 s. ISBN 0-256-12707-7.

TOMŠÍK, P., PROKEŠ, M., 2011: Formation of Regional Associations of Wine Producers in the Czech Republic. In: AGRARIAN PERSPECTIVES. 1. vyd. Praha: Czech University of Life Sciences Prague, s. 263-270. ISBN 978-80-213-2196-0.

TOMŠIK, P., SEDLO, J., ŠPERKOVÁ, R., 2007: Management vinařství a lidé, stavby, příroda. In Lidé, stavby a příroda 2007. 1. vyd. Brno: VUT v Brně, Fakulta stavební, s. 123-138. ISBN 978-807204-545-7.

ŽUFAN, P., 2002: Vnější a odvětvové prostředí pivovarnictvía výroby minerálních vod:habilitační práce. Brno: Mendelova zemědělská a lesnická univerzita v Brně, Provozně ekonomická fakulta, 148 s., 19 příl.

\section{Address}

Ing. Radka Šperková, Ph.D, Ing. Renata Skýpalová, Ústav managementu, Mendelova univerzita v Brně, Zemědělská 1, 61300 Brno, Česká republika, e-mail: radka.sperkova@gmail.com, renataskypalova@ centrum.cz 
